\title{
PENGGUNAAN MEDIA WAYANG UNTUK MENINGKATKAN KETERAMPILAN MENYIMAK CERITA PENDEK
}

\author{
Widayati \\ Kepala SDN Kepuharum Kec. Kutorejo Kab. Mojokerto \\ Email: waidayatiwidayati260@gmail.com
}

\begin{tabular}{l}
\hline Tersedia Online di \\
\hline http://www.jurnal.unublitar.ac.id/ \\
index.php/briliant \\
\hline \\
\hline Sejarah Artikel \\
\hline Diterima pada 2 Januari 2017 \\
Disetuji pada 20 Januari 2017 \\
Dipublikasikan pada 1 Februari \\
2017 Hal. 43 - 50 \\
\hline Kata Kunci: \\
\hline media wayang, menyimak, cerita \\
pendek
\end{tabular}

\begin{abstract}
Abstrak: Berdasarkan observasi, pembelajaran inilah yang membuat peneliti merasa ingin melakukan pembelajaran yang kreatif dan inovatif untuk meningkatkan hasil belajar di SD tersebut dengan berkolaborasi dengan gurunya. Jenis penelitian adalah penelitian tindakan kelas ini menggunakan metode penelitian kuantitatif dan kualitatif. Instrumen pengumpulan data dalam penelitian ini yaitu tes dan lembar angket. Subyek penelitian ini dilakukan pada siswa kelas V SDN Kepuharum Kutorejo. Prosedur penelitian meliputi tahapan perencanaan, tindakan, pengamatan, dan refleksi. Berdasarkan hasil analisis data dapat dilihat hasil tes siswa menunjukkan bahwa keterampilan menyimak cerita pendek meningkat. Pada pra siklus hasil belajar siswa dengan nilai rata-rata 55. Siklus I dengan nilai rata-rata 65 dan siklus II dengan nilai rata-rata 85 .
\end{abstract}

Tujuan pendidikan pada dasarnya mengantarkan para siswa menuju pada perubahan-perubahan tingkah laku baik intelek, moral maupun sosial. Dalam mencapai tujuan tersebut siswa berinteraksi dengan lingkungan belajar yang diatur guru melalui proses pembelajaran (Sudjana dan Rivai 2013:1). Dalam kegiatan pembelajaran, siswa adalah sebagai subjek dan sebagai objek dari kegiatan pembelajaran. Inti dari proses pembelajaran tidak lain adalah kegiatan belajar siswa dalam mencapai suatu tujuan pembelajaran. Keaktifan siswa tidak hanya dituntut dari segi fisik, tetapi segi kejiwaan. Bila hanya fisik yang aktif, tetapi pikiran dan mentalnya kurang aktif, maka kemungkinan besar tujuan pembelajaran tidak tercapai. Padahal belajar pada hakikatnya adalah "perubahan" yang terjadi di dalam diri seseorang setelah berakhirnya melakukan aktivitas belajar (Djamarah dan Zain 2010:38). Oleh karena itu pada kenyataannnya salah satu pertanda bahwa seseorang telah belajar adalah adanya perubahan tingkah laku pada diri orang itu yang mungkin disebabkan oleh terjadinya perubahan tingkat pengetahuan, ketrampilan, atau sikapnya.

Pembelajaran adalah proses yang secara kreatif menuntut siswa melakukan sejumlah kegiatan, sehingga siswa benar-benar membangun pengetahuannya secara mandiri dan berkembang pula kreativitasnya (Abidin, 2012:3). Bahasa Indonesia merupakan alat komunikasi yang digunakan dalam pembelajaran di kelas. Sementara itu bahasa Indonesia adalah mata pelajaran yang wajib diberikan dari jenjang sekolah dasar sampai dengan perguruan tinggi. 
Hal itu karena bahasa Indonesia merupakan bahasa nasional sekaligus bahasa negara Indonesia.

Dalam proses pembelajaran bahasa Indonesia siswa dituntut untuk mampu baca dan tulis. Didalam mata pelajaran bahasa Indonesia terdapat empat aspek yang perlu dikuasai, yaitu aspek mendengarkan, berbicara, membaca, dam menulis. Tarigan mengungkapkan (2008:1) ketrampilan berbahasa dalam kurikulum di sekolah biasanya mencakup empat segi, yaitu ketrampilan menyimak (mendengarkan), ketrampilan berbicara, ketrampilan menulis, dan ketrampilan membaca. Setiap ketrampilan tersebut erat sekali hubungannya dengan tiga ketrampilan lainnya dengan cara beraneka rona.

Standar kompetensi lulusan bahasa Indonesia menjabarkan mata pelajaran bahasa Indonesia memiliki empat keterampilan berbahasa, yaitu mendengarkan, berbicara, membaca, dan menulis (Faizun, 2012:51). Keempat keterampilan berbahasa tersebut harus mendapatkan porsi yang seimbang dan dalam pelaksanaannya dilakukan secara terpadu.

Ketrampilan dalam aspek bahasa dapat dimulai dari ketrampilan menyimak. Menyimak merupakan salah satu aspek yang terpenting dalam kesuksesan bahasa. Untuk mengetahui isi yang sedang dibicarakan membutuhkan sebuah konsentrasi yang penuh agar kita dapat menyimak dengan baik dan mengetahui apa isinya. Tetapi untuk menumbuhkan konsentrasi penuh bukan pekerjaan yang mudah.

Menyimak merupakan suatu proses kegiatan mendengarkan lambanglambang lisan dengan penuh perhatian, pemahaman, apresiasi, serta interpretasi untuk memperoleh informasi, menangkap isi atau pesan, serta memahami makna komunikasi yang telah disampaikan sang pembicara melalui ujaran atau bahasa lisan (Tarigan, 2008:31). Mendengar bersifat pasif dan spontan, sedangkan menyimak bersifat aktif. Menyimak menyangkut proses interpretasi terhadap informasi yang datang. Jadi dalam menyimak diperlukan konsentrasi, perhatian yang sungguh-sungguh kesengajaan, pemahaman, dan kehati-hatian. Sebab itu, ketrampilan menyimak perlu ditingkatkan supaya tidak mempengaruhi proses memperoleh informasi dan komunikasi.

Djamarah dan Zain (2010:120) berpendapat bahwa media merupakan wahana penyalur informasi belajar atau penyalur pesan. Gerlach dan Ely dalam Arsyad (2011:3) menyatakan bahwa media adalah manusia, materi, atau kejadian yang membangun kondisi yang membuat siswa mampu memperoleh pengetahuan, ketrampilan, atau sikap. Berdasarkan uraian diatas dapat disimpulkan bahwa media merupakan segala sesuatu yang menyalurkan pesan dan penerimanya dapat melakukan proses belajar.

Daryanto (2010:33) mengatakan bahwa wayang adalah benda tiruan dari bentuk manusia atau binatang. Media wayang merupakan sebuah media yang termasuk ke dalam jenis media visual yang berbentuk tiga dimensi, karena media ini dapat dilihat dan dipegang. Dalam pembelajaran bahasa Indonesia materi mengidentifikasi unsur cerita cara meragakan media ini guru bercerita dengan meragakan boneka yang sesuai dengan ceritanya. Jadi dalam hal ini, guru dituntut memerankan tokoh dalam cerita. Alasan peneliti menggunakan media ini karena peneliti ingin membuat pembelajaran menjadi lebih menarik selain itu, media ini 
dapat mempermudah siswa mengidentifikasi unsur cerita. Kelebihan media wayang ini lebih memperjelas pesan dan informasi sehingga mudah dipahami oleh siswa dan meningkatkan proses dan hasil pembelajaran. Dengan menggunakan media ini, tentunya apa yang disampaikan akan menjadi lebih menarik dan konsentrasi mengenai apa yang disampaikan oleh guru.

Teori belajar yang cocok digunakan dalam penelitian menyimak cerita pendek adalah teori belajar kontruktivisme. Karena teori ini sesuai dengan maksud peneliti untuk mengembangkan kreatifitas dari dalam diri siswa dengan media yang sangat dekat dengan siswa sehari-hari. Teori belajar konstruktivisme adalah suatu teori yang menekankan pada proses dan lebih menghargai pada pemunculan pertanyaan dan ide-ide siswa berdasarkan kehidupan nyata. Proses belajar sebagai suatu usaha pemberian makna oleh siswa kepada pengalamannya melalui proses asimilasi dan akomodasi, akan membentuk suatu konstruksi pengetahuan yang menuju pada kemutakhiran struktur kognitifnya. Guru-guru konstruktivistik yang mengakui dan menghargai dorongan diri manusia/siswa untuk mengkonstruksikan pengetahuan sendiri, kegiatan pembelajaran yang dilakukannya akan diarahkan agar terjadi aktivitas konstruksi pengetahuan oleh siswa secara optimal.

Kondisi pembelajaran di SDN Kepuharum Kutorejo tidak jauh berbeda dengan kondisi pembelajaran pada umumnya. Berdasarkan pelaksanaan pembelajaran, diketahui bahwa siswa lebih menyukai pembelajaran dengan bercerita dengan menggunakan media pada materi menyimak cerita pendek. pembelajaran menyimak cerita pendek selama ini masih menerapkan secara sederhana yaitu dengan berceramah. Sehingga aktivitas dan hasil belajar siswa pada materi menyimak cerita pendek kurang maksimal.

Situasi pembelajaran inilah yang membuat peneliti merasa ingin melakukan pembelajaran yang kreatif dan inovatif. Dengan menerapkan media wayang pada pembelajaran menyimak cerita pendek, diharapkan aktivitas siswa saat proses pembelajaran akan mengalami peningkatan. Peningkatan aktivitas siswa diharapkan lebih baik ketika menyimak cerita pendek dapat lebih berkonsentrasi dan sungguh-sungguh dalam menyimak cerita pendek menggunkan media wayang dan suasana kelas menjadi kondusif. Pada akhirnya hasil belajar akan bisa meningkat.

Berdasarkan pembahasan di atas maka, peneliti tertarik untuk menerapkan media wayak dalam upaya meningkatkan keterampilan menyimak Cerita Pendek pada Siswa Kelas V SDN Kepuharum Kecamatan Kutorejo Kabupaten Mojokerto.

\section{METODE}

\section{Rancangan Penelitian}

Jenis Penelitian ini adalah penelitian tindakan kelas (classroom action research) Penelitian tindakan kelas merupakan suatu pencermatan terhadap kegiatan belajar berupa sebuah tindakan, yang sengaja dimunculkan dan terjadi dalam sebuah kelas secara bersama.Tindakan tersebut diberikan oleh guru atau dengan arahan dari guru yang dilakukan oleh peserta didik. 


\section{Subjek Penelitian}

Subjek penelitian ini adalah peserta didik kelas V SDN Kepuharum Kecamatan Kutorejo Kabupaten Mojokerto tahun pelajaran 2014/2015 sebanyak 20 siswa. Sedangakan waktu penelitian dilaksanakan dilaksanakan pada semester genap.

\section{Instrumen Penelitian}

Instrumen penelitian adalah alat bantu yang dipilih dan digunakan oleh peneliti dalam kegiatannya mengumpulkan agar kegiatan tersebut menjadi sitematis dan dipermudah olehnya (Arikunto, 2009:101). Instrumen pada penelitian ini adalah tes dan observasi.

Observasi atau yang disebut pula dengan pengamatan, meliputi kegiatan pemuatan perhatian terhadap sesuatu objek dengan menggunakan seluruh alat indera. Dalam evaluasi pembelajaran observasi adalah kegiatan pengumpulan data yang digunakan untuk menilai proses dan hasil belajar peserta didik, seperti tingkah laku peserta didik pada waktu belajar, berdiskusi, mengerjakan tugas, dan lain-lain (Arifin, 2011:153). Lembar Tes dalam penelitian ini diuji dengan korelasi product moment dan reabilitas alpha yang sudah diuji divaliditas isi (contand validiti).

\section{Teknik Analisis Data}

Untuk menganalisis tingkat keberhasilan atau persentase keberhasilan peserta didik setelah proses pembelajaran setiap putarannya dilakukan dengan cara memberikan evaluasi berupa soal tes tertulis pada setiap akhir putaran. Analisis ini dihitung dengan menggunakan statistik sederhana yaitu: (1) Analisis aktivitas peserta didik. Analisis data aktivitas siswa pada lembar observasi dilakukan dengan memberi skor pada setiap aktivitas yang ada pada lembar observasi dengan kriteria skor. (2) Analisis ketuntasan data hasil belajar peserta didik. Berdasarkan kriteria ketuntasan minimal bahasa indonesia untuk kelas V SDN Kepuharum Kecamatan Kutorejo Kabupaten Mojokerto. Peserta didik dikatakan tuntas belajar pelajaran Bahasa Indonesia apabila secara individu memperoleh nilai 65 atau lebih. Untuk dapat mengetahui pencapaian ketuntasan belajar siswa, maka data berupa nilai yang diperoleh dengan mengadakan tes pada tiap siklus akan dianalisis dengan batas ketuntasan belajar siswa secara klasikal.

\section{HASIL PENELITIAN DAN PEMBAHASAN \\ Hasil Penelitian}

Sebelum diterapkan media wayang dikelas V SDN Kepuharum diperoleh siswa yang tuntas 9 siswa atau $45 \%$ dan yang tidak tuntas 11 siswa atau $55 \%$ dari 20 siswa. Sedangkan skor aktivitas belajar sebesar 55\%. Dengan demikian, peneliti menyimpulkan bahwa ketrampilan menyimak cerita pendek perlu ditingkatkan lagi, karena pada hasil yang dicapai pada pembelajaran yang telah dilakukan peneliti dalam prasiklus masih belum dapat mencapai KKM, sehingga perlu adanya perbaikan tindakan yang dilakukan oleh peneliti pada siklus I. Agar dapat mencapai hasil yang memuaskan maka peneliti akan menerapkan media wayang untuk meningkatkan ketrampilan siswa dalam menyimak cerita pendek. 
Tetapi, hasil pada prasiklus tersebut menunjukkan nilai yang dicapai sangat minimal, dan rata-rata kelas yang dicapai masih 55. Sedangkan batas KKM yaitu 70. Aspek yang belum tercapai antara lain: (1) Menentukan tema yang terdapat dalam cerita pendek dari judul cerita, siswa belum bisa mentukan tema apa yang terkandung dalam cerita pendek tersebut kebanyakan siswa menulis kembali judul cerita pendek tersebut. (2) Menentukan latar kejadian yang terdapat dalam cerita pendek, siswa masih belum dapat menetukan dimana kejadiankejadian yang ada dicerita pendek. (3) Menjelaskan amanat apa di dalam cerita yang terkandung dalam cerita pendek, siswa masih belum bisa untuk menjelaskan amanat apa yang terkandung dalam cerita pendek tersebut, umumnya mereka menjawab sama dengan temanya karena masih bingung dengan inti dari cerita itu. (3) menceritakan kembali isi cerita pendek dengan menggunakan bahasa sendiri, siswa masih kesulitan untuk menata kalimat yang ingin dituangkan dalam bentuk tulisan.

Pada siklus I, setelah diterapkan media wayang kelas V SDN Kepuharum Kutorejo Tahun Pelajaran 2014/2015 diperoleh siswa yang tuntas 12 siswa atau $60 \%$ dan yang tidak tuntas 8 siswa atau 40\% dari 20 siswa. Nilai ratarata hasil belajar sebesar 65 . Sedangkan skor aktivitas belajar siswa pada siklus I ini didapat sebesar $60 \%$.

Aspek yang belum tercapai pada siklus I antara lain: (1) menentukan latar yang terdapat dalam cerita pendek, siswa masih merasa kebingungan menentukan dimana tempat yang disebutkan dalam cerita pendek tersebut, (2) menjelaskan amanat yang didalam cerita pendek, masih belum bisa menjelaskan amanat yang terkandung dalam cerita pendek, (3) menceritakan kembali isi cerita dengan bahasa sendiri, banyak siswa yang belum bisa mengutarakan apa yang dipikirkan untuk dituangkan dalam bentuk tulisan.

Pada siklus II terjadi peningkatan ketrampilan menyimak cerita pendek dengan media wayang secara signifikan, bila dibandingkan dengan siklus I. Pada siklus II jumlah siswa yang tuntas mencapai 18 siswa atau $90 \%$ sedangkan yang belum tuntas ada 2 siswa atau 10\%. Nilai rata-rata hasil belajar sebesar 85 . Sedangkan aktivitas belajar siswa pada siklus II ini mengalami peningkat menjadi $80 \%$. Berdasarkan hasil ini, maka siklus II dinyatakan berhasil sehingga perbaikan pembelajaran yang selanjutnya tidak perlu dilakukan. Dengan demikian perbaikan pembelajaran dihentikan sampai dengan siklus II.

Data pada penelitian ini juga meliputi data non tes, yaitu data yang berupa lembar angket yang telah diisi oleh para siswa dan lembar pengamatan siswa oleh teman sejawat.Angket dibagiakan kepada siswa pada akhir pembelajaran dan harus diisi oleh semua siswa tanpa terkecuali. Berikut merupakan hasil angket pembelajaran menyimak cerita pendek dengan media wayang adalah berdasarkan angket yang telah diisi siswa, dapat diketahui bahwa semua siswa mengaku senang terhadap pembelajaran menyimak cerita pendek dengan media wayang. Hal ini terlihat saat proses pembelajaran berlangsung.

Setelah pembelajaran selesai, dengan adanya menyimak cerita pendek dengan media wayang, sebagian besar siswa mengaku lebih mudah dalam mengidentifikasi unsur cerita pendek dan mereka bisa menceritakan kembali dengan bahasa sendiri. Berdasarkan hasil ini, dapat dikatakan bahwa pada siklus II 
siswa sangat antusias terhadap pembelajaran menyimak cerita pendek dengan media wayang.

Aspek yang diamati selain lembar angket yaitu lembar observasi yang telah disiapkan peneliti dan diisi oleh teman sejawat. Lembar observasi yang diamati yaitu aktivitas siswa. Lembar observasi ini dibuat untuk mengetahi apa yang terjadi saat proses pembelajaran menyimak cerita pendek dengan menggunakan media wayang belangsung,

Berdasarkan lembar observasi aktivitas yang berjumlah 5 poin, diperoleh hasil bahwa semua hal suadah mencapai, yaitu (1) siswa memperhatikan penjelasan materi pembelajaran yang disampaikan oleh guru, (2) siswa aktif dalam kegiatan tanya jawab tentang materi ajar, (3) siswa aktif dan serius dalam kegiatan menyimak cerita pendek dengan media wayang, (4) siswa merespon umpan balik yang disampaikan oleh guru, (5) siswa tertib mengikuti setiap langkah-langkah pembelajaran.

\section{Pembahasan}

Berdasarakan deskripsi hasil pengamatan tindakan, serta paparan hasil penelitian yang meliputi peningkatan keterampilan menyimak cerita pendek dengan menggunakan media wayang, hasil belajar siklus I dan II terjadi peningkatan pembelajaran menyimak cerita pendek menggunakan media wayang dari siklus I sampai dengan siklus II. Berikut adalah tabel jumlah siswa yang mencapai nilai KKM yang sudah ditentukan sekolah:

Tabel 1 Jumlah Peningkatan Siswa Menyimak Cerita Pendek

\begin{tabular}{|c|c|c|c|}
\hline No & Kegiatan & Jumlah siswa tidak tuntas & Jumlah siswa yang tuntas \\
\hline 1 & PRASIKLUS & 11 siswa & 9 siswa \\
\hline 2 & SIKLUS I & 8 siswa & 12 siswa \\
\hline 3 & SIKLUS II & 2 siswa & 18 siswa \\
\hline
\end{tabular}

Dakam bentuk grafik peneliti sajikan pada gambar 1 berikut :

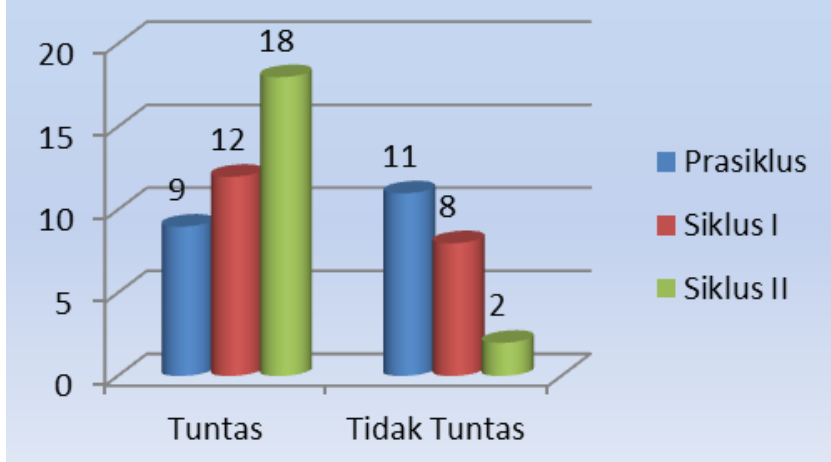

Gambar 1. Perbandingan hasil belajar prasiklus, siklus I dan siklus II

48 BRILLIANT: Jurnal Riset dan Konseptual

Volume 2 Nomor 1, Februari 2017 
Pembelajaran siklus I hanya 12 siswa yang memperoleh nilai di atas KKM, namun pada siklus II ada peningkatan yang cukup bagus 18 dari 20 siswa mampu memperoleh nilai di atas KKM yang sudah ditentukan. Hal tersebut nenunjukkan siswa menjadi termotivasi dalam menyimak cerita pendek seteah menggunak media wayang.

Hasil analisis aktivitas siswa prasiklus, siklus I dan siklus II peneliti sajikan pada tabel dan gambar berikut :

Tabel 2 Aktivitas belajar siswa menyimak cerita pendek

\begin{tabular}{|c|c|c|}
\hline No & Kegiatan & Skor perolehan \\
\hline 1 & PRASIKLUS & $55 \%$ \\
\hline 2 & SIKLUS I & $60 \%$ \\
\hline 3 & SIKLUS II & $80 \%$ \\
\hline
\end{tabular}

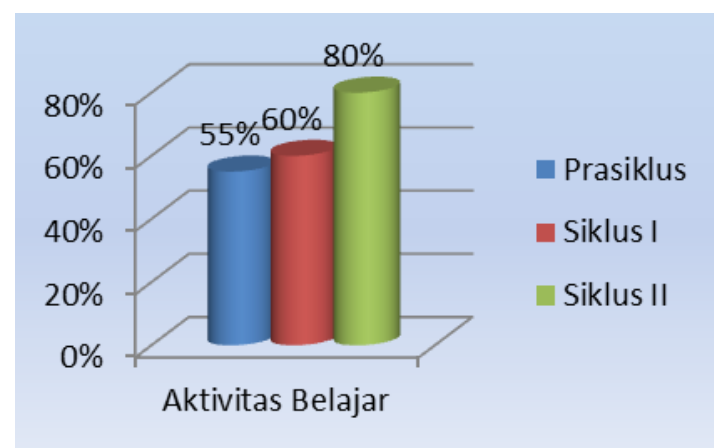

\section{Gambar 2. Perbandingan aktivitas belajar prasiklus, siklus I dan II}

\section{KESIMPULAN}

Berdasarkan hasil penelitian meningkatkan keterampilan menyimak cerita pendek dengan menggunakan media wayang pada siswa kelas V SDN Kepuharum Kecamatan Kutorejo Mojokerto tahun Pelajaran 2014/2015, dapat disimpulkan bahwa penggunaan media wayang cukup meningkatkan pembelajran menyimak siswa. Terbukti dengan analisis dan penelitian tindakan kelas yang telah dilaksanakan, maka diperoleh data-data dan sumber data yang terkumpul yang kemudian di analisis dan ditemukan hambatan-hambatan yang terjadi selama proses pembelajaran berlangsung.

Hasil belajar siswa prasiklus mendapatkan nilai rata-rata 55 hal ini dikarenakan masih kurang, siswa belum mampu menentukan tema, latar, amanat, dan menceritakan kembali dengan bahasa sendiri dari cerita pendek tersebut. Siklus I siswa mendapatkan nilai rata-rata 65 . Siklus I menunjukkan peningkatan dibandingkan pra siklus tetapi belum mencapai KKM. Kebanyakan siswa masih 
belum bisa menentukan tema, amanat dan menceritakan kembali cerita pendek dengan menggunakan bahasa sendiri. Siklus II mendapatkan nilai rata-rata 85, dari hasil siklus II dapat diketahui bahwa siswa sudah memahami dan menetukan unsur cerita pendek dan menceritakanya kembali dengan bahasa sendiri. Pada aktivitas belajar siswa juga terjadi peningkatan pada prasiklus diperoleh skor $55 \%$ meningkat menjadi $60 \%$ pada siklus I dan meningkat lagi menjadi $80 \%$ pada siklus II. Dapat disimpulkan terjadi peningkatan aktivitas belajar dan hasil belajar dari pra siklus, siklus I, dan siklus II dengan menggunakan media wayang dilakukan di kelas V SDN Kepuharum Kecamatan Kutorejo Kabupaten Mojokerto.

\section{SARAN}

Berdasarkan penelitian yang telah dilaksanakan penelitian di SDN Kepuharum Kutorejo, peneliti mengemukakan saran-saran sebagai berikut: (1) Bagi guru diharapkan lebih mengoptimalkan bila menjelasakan pada materi cerita pendek menggunakan media wayang karena siswa lebih mudah mengidentifikasi unsur-unsur cerita. (2) Bagi siswa disarankan dalam proses pembelajaran diharapkan lebih aktif dan berkonsentrasi terhadap pembelajaran yang diajarkan sebab terkadang siswa mengobrol dengan teman sebangkunya, faktor tersebut yang menghambat dalam pembelajaran. (3) Bagi peneliti disarankan agar lebih kreatif lagi membuat media supaya siswa lebih tertarik dengan pembelajaran yang diberikan, sehingga mampu meningkatkan keterampilan menyimak siswa.

\section{DAFTAR PUTAKA}

Abidin, Yunus. 2012. Pembelajaran Membaca Berbasis Pendidikan Karakter. Bandung: PT Refika Aditama.

Arikunto, S.2009.Manajemen Penelitian.Jakarta:Rineka Cipta

Djamarah, Zain. 2010. Strategi Belajar Mengajar. Jakarta: Rineka Cipta.

Faizun.2012. Kurikulum Bahan Perkuliah Prodi Stkip Jombang. Jombang: STKIP Sudjana dan Rivai. 2013. Media Pengajaran. Bandung: Sianr Baru Algensindo

Tarigan, Henry guntur. 2008. Menulis Sebagai Suatu Ketrampilan Berbahasa. Bandung: Angkasa. 